\title{
ISOLASI Escherichia coli DARI URINE PASIEN INFEKSI SALURAN KEMIH DI RUMAH SAKIT BHAYANGKARA KEDIRI
}

\section{ISOLATION OF Escherichia coli FROM URINE OF PATIENTS OF URINARY TRACT INFECTION IN BHAYANGKARA KEDIRI HOSPITAL}

\author{
Mastuti Widianingsih ${ }^{1 *}$, Aldino Marcos de Jesus ${ }^{2}$ \\ ${ }^{I}$ Fakultas Ilmu Kesehatan, Institut Ilmu Kesehatan Bhakti Wiyata, Jl. K.H. Wahid Hasyim No. 65, Kediri, Jawa Timur, \\ 64114 \\ ${ }^{2}$ Laboratorium Bakteriologi, Institut Ilmu Kesehatan Bhakti Wiyata, Jl. K.H. Wahid Hasyim No. 65, Kediri, Jawa \\ Timur, 64114 \\ *Corresponding author: widianingsihmastuti910224@gmail.com
}

Naskah Diterima: 5 September 2017; Direvisi: 1 Mei 2018; Disetujui: 3 Mei 2018

\begin{abstract}
Abstrak
Infeksi saluran kemih (ISK) terjadi akibat adanya invasi mikroorganisme (bakteri) pada saluran kemih. Peningkatan kejadian ISK dapat dipengaruhi oleh kondisi refluks vesikouretral (RVU), obstruksi saluran kemih, pemakaian instrumen uretral baru, dan septikimia. Angka kejadian ISK di Rumah Sakit Bhayangkara Kediri tahun 2016 berjumlah 346 kasus. Penelitian ini bertujuan untuk mengetahui ada tidaknya Escherichia coli pada urine pasien ISK di Rumah Sakit Bhayangkara Kediri. Besarnya persentase ISK yang disebabkan $E$. coli mendorong peneliti untuk melakukan isolasi bakteri tersebut dari urine pasien ISK di rumah sakit tersebut. Teknik sampling yang digunakan berupa Accidental sampling dengan sampel berupa urine porsi tengah (UPT) sebanyak 30. Sampel urine diinokulasikan pada media MCA, kemudian dilakukan pewarnaan Gram, dilanjutkan uji biokimia reaksi untuk membedakan golongan Enterobacter. Hasil penelitian menunjukkan bahwa 12 sampel positif mengandung E. coli, 3 sampel mengandung Klebsiella spp., dan 15 sampel tidak terdeteksi sama sekali. Hasil positif E. coli ditunjukkan dengan koloni bulat berukuran kecil, elevasi semi mucoid, dan fermentasi laktosa positif pada media MCA. Hal tersebut menunjukkan bahwa E. coli dapat ditemukan pada sampel urine pasien ISK di Rumah Sakit Bayangkara Kediri.
\end{abstract}

Kata kunci: Escherichia coli; ISK; RS Bhayangkara Kediri

\begin{abstract}
Urinary tract infection (UTI) is caused by microbial invasion (bacteria) in the urinary tract. The increased of UTI can be affected by a condition of vesicouretral reflux (RVU), urinary tract obstruction, application of new urethral instruments, and septicemia. The incidence of UTI in Bhayangkara Kediri Hospital in 2016 was 346 cases. The objective of this research was to determine the presence of E. coli in UTI patients in the Bhayangkara Kediri Hospital. The large percentage of UTI caused by Escherichia coli encouraged researchers to isolate the bacteria from the urine of UTI patients in the hospital. Accidental sampling with 30 middle portion urine samples (UPT) was carried out. The samples were inoculated onto separate MCA media. Representative bacterial isolates were stained with Gram staining technique and followed by reaction biochemistry tests to distinguish Enterobacter groups. The results showed that 12 urine samples contained E. coli, 3 urine samples contained Klebsiella spp., while 15 urine samples were negative (not containing bacteria). The positive results of E. coli showed small rounded, elevation of semi mucoid colonies, and positive lactose fermentation on the MCA media. It showed that E. coli indeed exists in the urine samples of UTI patients in Bayangkara Kediri Hospital.
\end{abstract}

Keywords: Bhayangkara Kediri Hospital; Escherichia coli; UTI

Permalink/DOI: http://dx.doi.org/10.15408/kaunivah.v11i2.5899 


\section{PENDAHULUAN}

Infeksi saluran kemih (ISK) menempati urutan kedua penyakit infeksi terbanyak setelah infeksi saluran pernafasan. Hasil pemeriksaan simtomatik per tahun menunjukkan bahwa sekitar 100.000 pasien melakukan rawat inap dan 7 juta pasien melakukan rawat jalan akibat ISK (Prakasam et al., 2012; Nordstrom et al., 2013; Alkhyat \& Al-Maqtari, 2014). Di Indonesia, prevalensi kejadian ISK cukup tinggi yaitu 180.000 kasus/tahun (Depkes RI, 2014; Darsono et al., 2016).

Infeksi saluran kemih merupakan kondisi akibat terjadinya invasi mikroorganisme pada saluran kemih. Peningkatan kejadian ISK dapat dipengaruhi oleh kondisi refluks vesikouretral (RVU), obstruksi saluran kemih, pemakaian instrumen uretral baru, dan septikimia. Resiko terkena ISK pada wanita lebih tinggi dibandingkan pada pria (Samirah et al., 2006; Sumolang et al., 2013). Hal tersebut salah satunya karena jarak antara uretra dengan rektum pada pria lebih jauh dibandingkan wanita, selain itu, kandungan bakterisidal yang ada pada kelenjar prostat dapat melindungi pria dari kejadian ISK (Prabowo \& Habib, 2012).

Secara umum ISK dibagi menjadi dua, yaitu ISK bagian bawah dan ISK bagian atas. Infeksi saluran kemih bagian bawah menjadi kasus yang sering terjadi. Kasus tersebut karena masuknya bakteri melalui uretra (Bien et al., 2012). Infeksi dapat terjadi melalui inflamasi pada kelenjar prostat, peradangan pada vesika urinaria atau kandung kemih, serta peradangan yang mengakibatkan luka pada uretra. Infeksi saluran kemih bagian atas dapat mengakibatkan gangguan fungsi ginjal (pielonefritis), pembengkakan nefron, dan abses renal (Samirah et al., 2006; Bien et al., 2012).

Peningkatan usia seseorang berbanding lurus dengan kemungkinan terkena ISK. Hal tersebut terkait dengan fungsi kelenjar prostat pada pria dan degenerasi fungsi estrogen pada wanita menopause. Pasien infeksi saluran kemih di RSUP Prof. dr. R. D. Kandau Manado didominasi oleh pasien wanita dengan usia 50-59 tahun. Kasus tersebut mulai mengalami peningkatan jumlah pada wanita usia di atas 40 tahun (Sumolang et al., 2013), sementara di Rumah Sakit Dr. Wahidin Sudirohusodo, hasil penelitian distribusi ISK menunjukkan bahwa wanita usia 46-75 tahun memiliki resiko tertinggi terkena ISK. Data tersebut diperoleh dari pemeriksaan urine penderita ISK usia 0 sampai lebih dari 75 tahun sebanyak 100 pasien (45 laki-laki dan 54 wanita) (Samirah et al., 2006).

Keberadaan ISK ditandai dengan nyeri suprapubik, disiuria, hematuria, urgensi, dan straguria, bahkan ada yang disertai demam, muntah, dan nyeri punggung (Geografi et al., 2014). Bakteri Gram negatif seperti E. coli, Proteus mirabilis, Klebsiella spp., Citrobacter spp., Enterobacter spp., dan Pseudomonas spp. merupakan bakteri yang sering menyebabkan ISK. Beberapa hasil penelitian menunjukkan E. coli mengakibatkan 80-95\% kejadian ISK (Prakasam et al., 2012; Alkhyat \& Al-Maqtari, 2014; Jarvis et al., 2014; Kibret \& Abera, 2014; Swetha et al., 2014).

Bakteriuria dikatakan bermakna apabila ditemukan 100.000 bakteri patogen $/ \mathrm{mL}$ urine porsi tengah (Sumolang et al., 2013). Angka kejadian ISK di Rumah Sakit Bhayangkara Kediri tahun 2016 yaitu sebanyak 53 pasien rawat jalan dan 293 pasien rawat inap. Selama ini belum diketahui adanya penelitian terkait pemeriksaan bakteri yang ada pada urine pasien ISK di Rumah Sakit Bhayangkara Kota Kediri. Besarnya persentase ISK yang disebabkan E. coli mendorong peneliti untuk melakukan isolasi bakteri tersebut pada pasien ISK di Rumah Sakit Bhayangkara Kediri. Tujuannya guna mengetahui keberadaan $E$. coli penyebab ISK pada pasien yang diduga terkena ISK di Rumah Sakit Bhayangkara Kota Kediri.

\section{MATERIAL DAN METODE Sampel}

Penelitian ini menggunakan teknik Accidental sampling dengan 30 sampel urine berupa urine porsi tengah. Sampel urine porsi tengah merupakan urine yang paling baik untuk pemeriksaan ISK karena urine bebas kontaminasi (Sumolang et al., 2013; Samirah et al., 2014). Aliran pertama urine berfungsi untuk membuang sel-sel dan mikroorganisme dari luar uretra agar tidak mencemari spesimen urine (Mamonto et al., 2015). Urine didapatkan dari pasien ISK di Rumah Sakit Bhayangkara Kediri. Pasien yang dipilih 
adalah pasien penderita ISK tanpa melihat usia dan jenis kelamin.

\section{Inokulasi pada Media Selektif Mac Conkey Agar (MCA)}

Sebelum dilakukan inokulasi, sebanyak 5-10 mL sampel urine disentrifugasi selama 10 menit dengan kecepatan 2.500-3.000 rpm. Sentrifugasi bertujuan mengendapkan materi lain yang ada di dalam urine selain bakteri. Isolasi E. coli dilakukan dengan melakukan inokulasi sampel urine ke media diferensial Mac Conkey Agar (MCA) (Swetha et al., 2014; Yadav et al., 2014). Biakan diinkubasi selama 24 jam pada suhu $37{ }^{\circ} \mathrm{C}$, kemudian dilakukan pewarnaan Gram pada isolat-isolat terpilih (representatif).

\section{Pewarnaan Gram}

Pewarnaan Gram dilakukan untuk mengetahui kelompok bakteri yang ada dalam sampel urine. Bakteri E. coli adalah bakteri Gram negatif, berbentuk batang, serta tersusun menyebar (Jawetz et al., 2013).

\section{Inokulasi pada Media Biokimia Reaksi}

Koloni dengan ciri berbentuk bulat, berukuran kecil, berwarna merah, memiliki tepi rata, permukaan cembung, semi mucoid, dan dengan hasil fermentasi laktosa positif pada MCA (hasil didapat setelah inkubasi selama 24 jam pada suhu $37{ }^{\circ} \mathrm{C}$ ), dilanjutkan inokulasi pada media reaksi biokimia. Media biokimia reaksi yang digunakan adalah medium dengan kandungan gula (glukosa, laktosa, maltosa, manisa, atau sukrosa) sebagai sumber karbon, medium Kliger Iron agar (KIA), urea, medium untuk menguji motilitas, dan medium IMVIC (indol, MR, VP, Citrat) (Prabowo \& Habib, 2012).

\section{HASIL}

Hasil isolasi E. coli pada pasien ISK di Rumah Sakit Bhayangkara Kediri tersaji pada Tabel 1 dan Tabel 2, serta persentase isolasi $E$. coli tersaji pada Gambar 1.

Data pada Tabel 1 dan Gambar 1 menunjukkan bahwa sampel yang dinyatakan negatif lebih banyak dibandingkan dengan yang positif ditemukan adanya $E$. coli ataupun bakteri lain (dalam penelitian ini ditemukan Klebsiella spp.). Koloni E. coli dan Klebsiella (Gambar 2) memiliki ciri-ciri yang hampir sama pada media diferensial (MCA), hanya bentuk dan elevasi yang berbeda. Koloni $E$. coli memiliki bentuk bulat kecil dan semi mucoid, sementara koloni Klebsiella spp. memiliki bentuk bulat besar dengan elevasi mucoid. Adanya kandungan crystal violet dan garam empedu pada media seletif MCA menjadikan pertumbuhan bakteri Gram positif terhambat (Ray, 2004; Yadav et al., 2014).

Uji biokimia reaksi melibatkan 12 set media yaitu media uji fermentasi gula sebanyak 5 macam (glukosa, laktosa, manosa, maltosa, dan sukrosa), media uji motil, media KIA, media urea, media indol, media MR, media VP, dan media uji citrat (Tabel 2). Isolat bakteri dinyatakan positif dapat memfermentasi gula yang diujikan apabila media yang semula berwarna hijau berubah menjadi kuning ataupun terbentuk gas. Hasil fermentasi berupa gas ditandai dengan adanya gelembung udara di dalam tabung Durham ataupun tabung Durham yang terangkat. Hal tersebut menandakan bakteri mampu memfermentasi karbohidrat (Gambar 3). Terbentuknya cincin merah pada permukaan media indol, MR, dan VP, menandakan hasil positif (Gambar 4 dan Gambar 5). Cincin merah pada media indol menunjukkan kemampuan bakteri dalam mendegradasi asam amino triptofan. Asam amino triptofan merupakan asam amino esensial yang dapat didegradasi oleh beberapa spesies bakteri dengan menghasilkan produk berupa indol, asam amino, dan piruvat. Produk indol dapat diketahui dengan mereaksikan biakan pada media indol dengan reagent Kovac's dengan hasil terbentuknya cincin merah (Hemraj et al., 2013).

Media VP berfungsi untuk mengetahui kemampuan bakteri dalam menghasilkan acetylmethylcarbinol atau acetoin. Hal tersebut dipengaruhi oleh penguraian glukosa. Apabila terjadi penguraian glukosa, kemudian hasil penguraian bereaksi dengan alpha-naphthol dan calium hidroxide (KOH) maka akan terbentuk warna merah atau cincin merah sebagai indikator adanya acetoin. Methyle Red adalah reagent yang direaksikan dengan media MR. Reagent itu berfungsi mendeteksi bakteri dalam menghasilkan campuran asam sebagai produk fermentasi glukosa. Reagent akan membentuk warna merah apabila kondisi media berada pada $\mathrm{pH}$ 4,4 (asam) yang 
menunjukkan hasil MR positif (Hemraj et al., 2013).

Tabel 1. Hasil pengamatan koloni pada Mac Conkey Agar (MCA)

\begin{tabular}{|c|c|c|c|c|c|c|c|}
\hline $\begin{array}{l}\text { Kode sampel } \\
\text { urine }\end{array}$ & Bentuk & Warna & Tepi & Permukaan & Elevasi & Fermentasi & Keterangan \\
\hline 1 & $\begin{array}{l}\text { Bulat, } \\
\text { kecil }\end{array}$ & Merah & Rata & Cembung & Semi mucoid & Laktosa + & E. coli \\
\hline 2 & $\begin{array}{l}\text { Bulat, } \\
\text { kecil }\end{array}$ & Merah & Rata & Cembung & Semi mucoid & Laktosa + & E. coli \\
\hline 3 & - & - & - & - & - & - & - \\
\hline 4 & - & - & - & - & - & - & - \\
\hline 5 & - & - & - & - & - & - & - \\
\hline 6 & $\begin{array}{l}\text { Bulat, } \\
\text { kecil }\end{array}$ & Merah & Rata & Cembung & Semi mucoid & Laktosa + & E. coli \\
\hline 7 & - & - & - & - & - & - & - \\
\hline 8 & $\begin{array}{l}\text { Bulat, } \\
\text { besar }\end{array}$ & Merah & Rata & Cembung & Mucoid & Laktosa + & $\begin{array}{l}\text { Klebsiella } \\
\text { spp. }\end{array}$ \\
\hline 9 & $\begin{array}{l}\text { Bulat, } \\
\text { kecil }\end{array}$ & Merah & Rata & Cembung & Semi mисоid & Laktosa + & E. coli \\
\hline 10 & - & - & - & - & - & - & - \\
\hline 11 & - & - & - & - & - & - & - \\
\hline 12 & $\begin{array}{l}\text { Bulat, } \\
\text { besar }\end{array}$ & Merah & Rata & Cembung & Mucoid & Laktosa + & $\begin{array}{l}\text { Klebsiella } \\
\text { spp. }\end{array}$ \\
\hline 13 & $\begin{array}{l}\text { Bulat, } \\
\text { kecil }\end{array}$ & Merah & Rata & Cembung & Semi mucoid & Laktosa + & E. coli \\
\hline 14 & - & - & - & - & - & - & - \\
\hline 15 & $\begin{array}{l}\text { Bulat, } \\
\text { kecil }\end{array}$ & Merah & Rata & Cembung & Semi mucoid & Laktosa + & E. coli \\
\hline 16 & $\begin{array}{l}\text { Bulat, } \\
\text { besar }\end{array}$ & Merah & Rata & Cembung & Mucoid & Laktosa + & $\begin{array}{l}\text { Klebsiella } \\
\text { spp. }\end{array}$ \\
\hline 17 & - & - & - & - & - & - & - \\
\hline 18 & - & - & - & - & - & - & - \\
\hline 19 & - & - & - & - & - & - & - \\
\hline 20 & $\begin{array}{l}\text { Bulat, } \\
\text { kecil }\end{array}$ & Merah & Rata & Cembung & Semi mисоid & Laktosa + & E. coli \\
\hline 21 & - & - & - & - & - & - & - \\
\hline 22 & $\begin{array}{l}\text { Bulat, } \\
\text { kecil }\end{array}$ & Merah & Rata & Cembung & Semi mucoid & Laktosa + & E. coli \\
\hline 23 & $\begin{array}{l}\text { Bulat, } \\
\text { kecil }\end{array}$ & Merah & Rata & Cembung & Semi mucoid & Laktosa + & E. coli \\
\hline 24 & - & - & - & - & - & - & - \\
\hline 25 & $\begin{array}{l}\text { Bulat, } \\
\text { kecil }\end{array}$ & Merah & Rata & Cembung & Semi mucoid & Laktosa + & E. coli \\
\hline 26 & - & - & - & - & - & - & - \\
\hline 27 & - & - & - & - & - & - & - \\
\hline 28 & - & - & - & - & - & - & - \\
\hline 29 & $\begin{array}{l}\text { Bulat, } \\
\text { kecil }\end{array}$ & Merah & Rata & Cembung & Semi mисоid & Laktosa + & E. coli \\
\hline 30 & $\begin{array}{c}\text { Bulat, } \\
\text { kecil }\end{array}$ & Merah & Rata & Cembung & Semi mucoid & Laktosa + & E. coli \\
\hline
\end{tabular}

Keterangan: - = tidak ditemukan adanya koloni E. coli dan Klebsiella spp. 
Tabel 2. Hasil pengamatan kultur pada media biokimia

\begin{tabular}{|c|c|c|c|c|c|c|c|c|c|c|c|c|}
\hline \multirow[b]{2}{*}{$\begin{array}{c}\text { Kode } \\
\text { sampel } \\
\text { urine }\end{array}$} & \multicolumn{5}{|c|}{ Gula-gula } & \multirow[b]{2}{*}{ Motil } & \multicolumn{4}{|c|}{ KIA } & \multirow[b]{2}{*}{ Urea } & \multirow[b]{2}{*}{ IMVIC } \\
\hline & $\begin{array}{l}\tilde{J} \\
0 \\
\frac{0}{3} \\
\frac{3}{0}\end{array}$ & 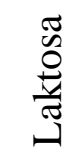 & 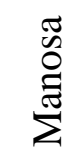 & $\begin{array}{l}\frac{\pi}{0} \\
\stackrel{0}{0} \\
\sum\end{array}$ & 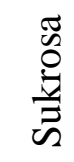 & & $\mathrm{L}$ & $\mathrm{D}$ & Gas & $\mathrm{H}_{2} \mathrm{~S}$ & & \\
\hline 1 & $(+)$ & $(+)$ & $(+)$ & $(+)$ & $(+)$ & - & Acid & Acid & + & - & - & ++-- \\
\hline 2 & $(+)$ & $(+)$ & $(+)$ & $(+)$ & $(+)$ & - & Acid & Acid & + & - & - & ++-- \\
\hline 6 & $(+)$ & $(+)$ & $(+)$ & $(+)$ & $(+)$ & - & Acid & Acid & + & - & - & ++-- \\
\hline 8 & $(+)$ & + & + & + & + & + & Acid & Acid & + & - & - & --++ \\
\hline 9 & $(+)$ & $(+)$ & $(+)$ & $(+)$ & $(+)$ & - & Acid & Acid & + & - & - & ++-- \\
\hline 12 & $(+)$ & + & + & + & + & + & Acid & Acid & + & - & - & --++ \\
\hline 13 & $(+)$ & $(+)$ & $(+)$ & $(+)$ & $(+)$ & - & Acid & Acid & + & - & - & ++-- \\
\hline 15 & $(+)$ & $(+)$ & $(+)$ & $(+)$ & $(+)$ & - & Acid & Acid & + & - & - & ++-- \\
\hline 16 & $(+)$ & + & + & + & + & + & Acid & Acid & + & - & - & --++ \\
\hline 20 & $(+)$ & $(+)$ & $(+)$ & $(+)$ & $(+)$ & - & Acid & Acid & + & - & - & ++-- \\
\hline 22 & $(+)$ & $(+)$ & $(+)$ & $(+)$ & $(+)$ & - & Acid & Acid & + & - & - & ++-- \\
\hline 23 & $(+)$ & $(+)$ & $(+)$ & $(+)$ & $(+)$ & - & Acid & Acid & + & - & - & ++-- \\
\hline 25 & $(+)$ & $(+)$ & $(+)$ & $(+)$ & $(+)$ & - & Acid & Acid & + & - & - & ++-- \\
\hline 29 & $(+)$ & $(+)$ & $(+)$ & $(+)$ & $(+)$ & - & Acid & Acid & + & - & - & ++-- \\
\hline 30 & $(+)$ & $(+)$ & $(+)$ & $(+)$ & $(+)$ & - & Acid & Acid & + & - & - & ++-- \\
\hline
\end{tabular}

Keterangan: Tanda kurung ( ) pada media yang mengandung gula menunjukkan terbentuknya gas

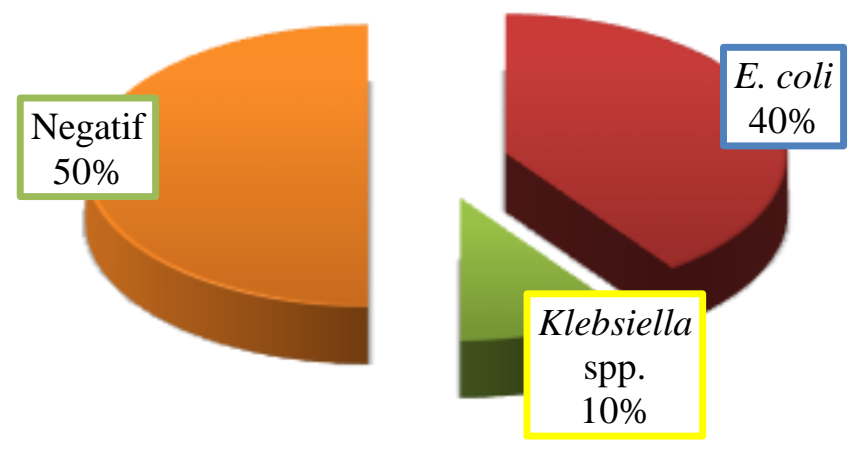

Gambar 1. Persentase komposisi bakteri pada urine penderita ISK di Rumah Sakit Bhayangkara Kediri

Citrate digunakan sebagai indikator dalam membedakan bakteri enterik dalam menggunakan citrate sebagai sumber karbon. Bromothymol blue berfungsi sebagi indikator perubahan warna hijau menjadi biru pada media tersebut. Hidrolisis citrat menjadi oksaloasetat dan asetat melibatkan enzim citrate permease. Oksaloasetat yang terbentuk kemudian dihidrolisis menghasilkan piruvat dan karbondioksida. Karbondioksida akan bereaksi dengan ion natrium dan air sehingga terbentuk natrium karbonat. Senyawa nantrium karbonat akan menjadikan perubahan warna media menjadi hijau dikarenakan senyawa tersebut bersifat alkali (Gambar 6). Hasil uji pada media IMVIC membedakan antara $E$. coli dan Klebsiella spp. (Hemraj et al., 2013). 


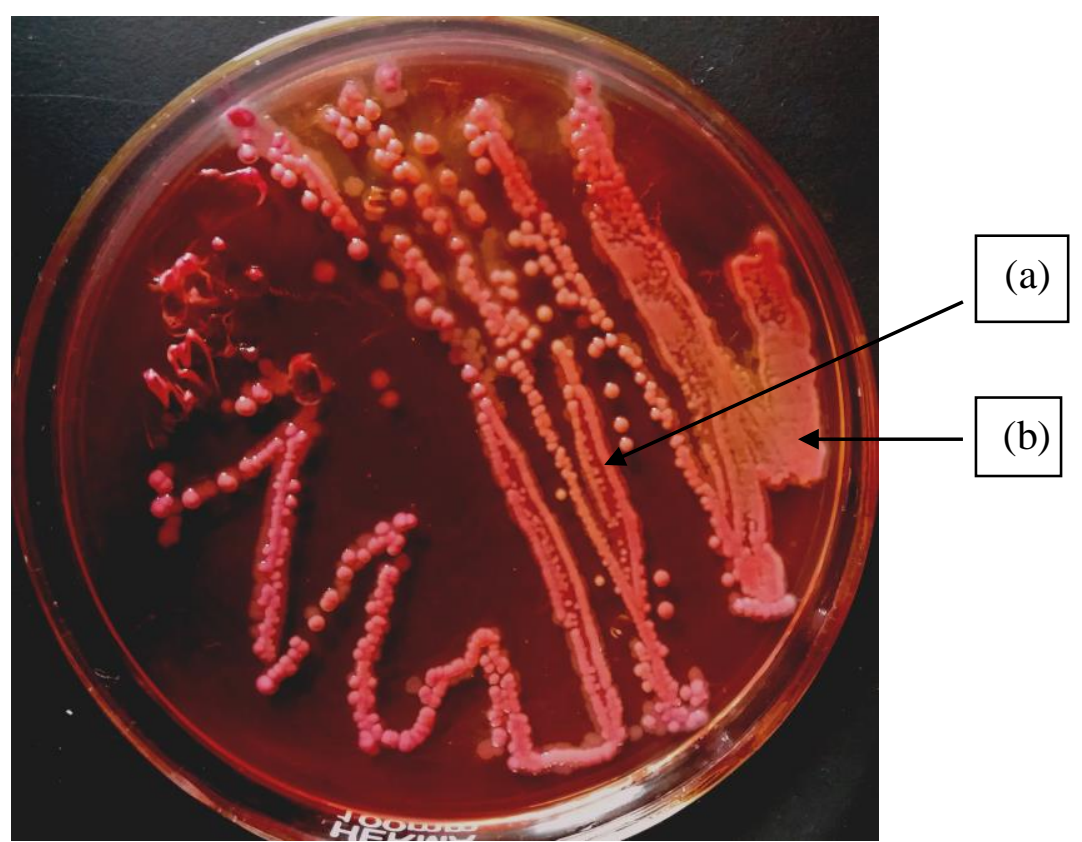

Gambar 2. Hasil inokulasi sampel urine pada Mac Conkey Agar (MCA). (a) E. coli dan (b) Klebsiella spp.

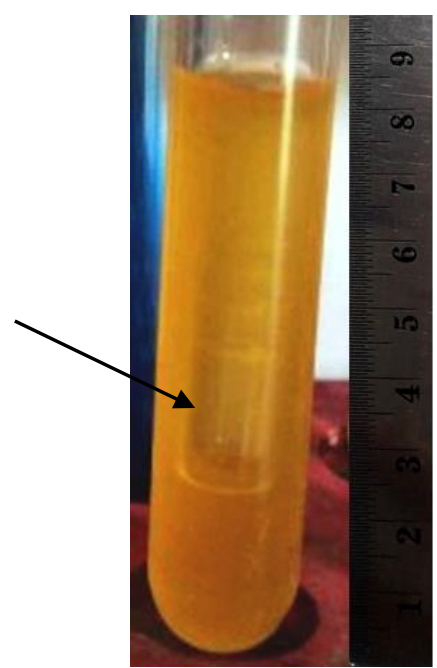

Gambar 3. Hasil fermentasi karbohidrat. Tanda panah menunjukkan adanya gas dalam tabung Durham

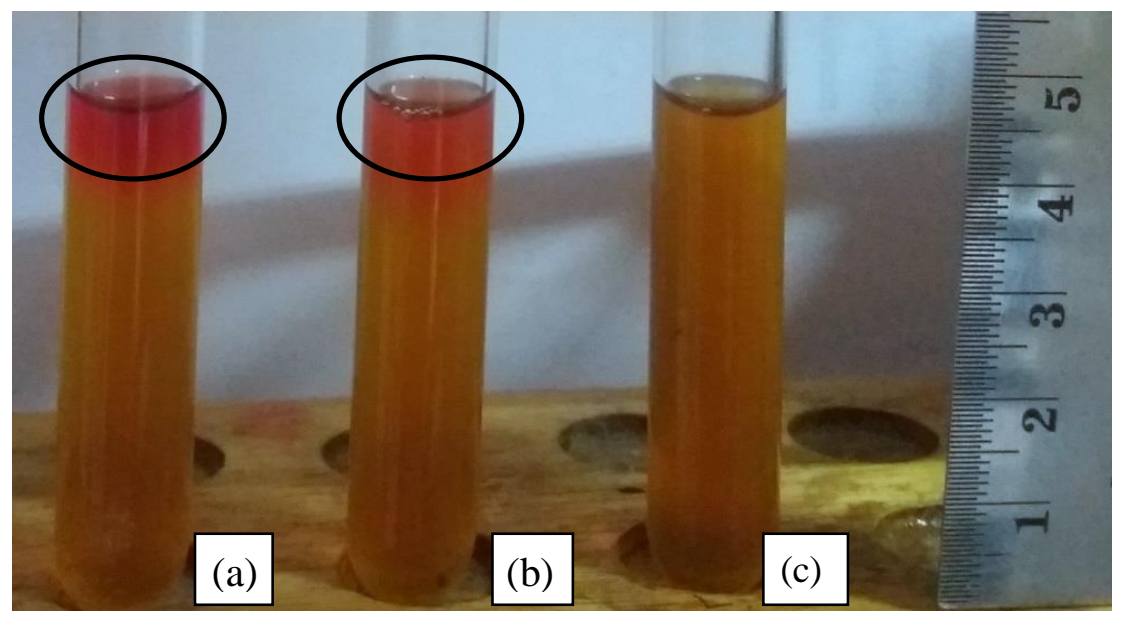

Gambar 4. Hasil uji (a) Indol, (b) MR, dan (c) VP pada E. coli. Uji indol dan MR bernilai positif ditunjukkan dengan adanya cincin/warna merah pada media 


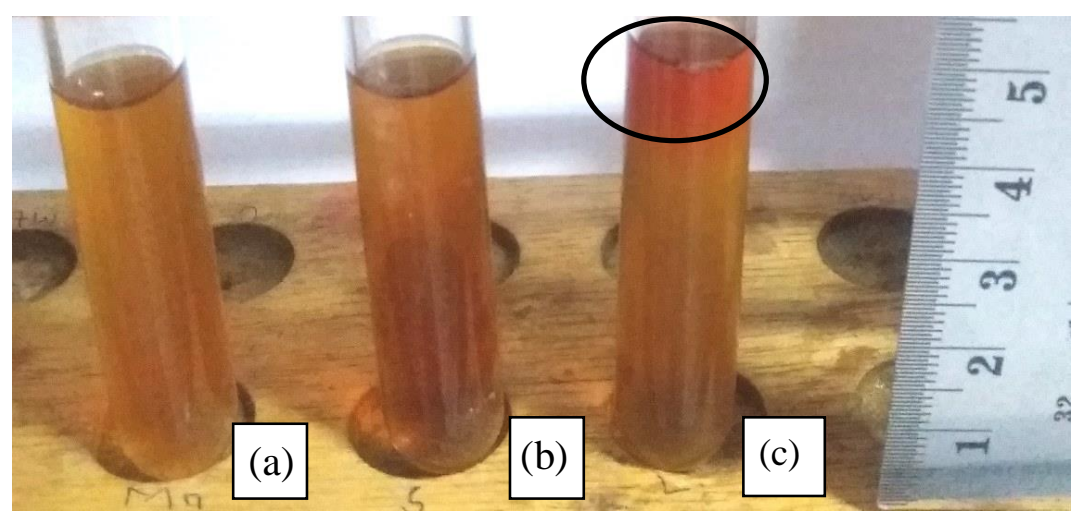

Gambar 5. Hasil uji (a) Indol, (b) MR, dan (c) VP pada Klebsiella spp. Uji VP bernilai positif ditunjukkan dengan adanya cincin/warna merah pada media
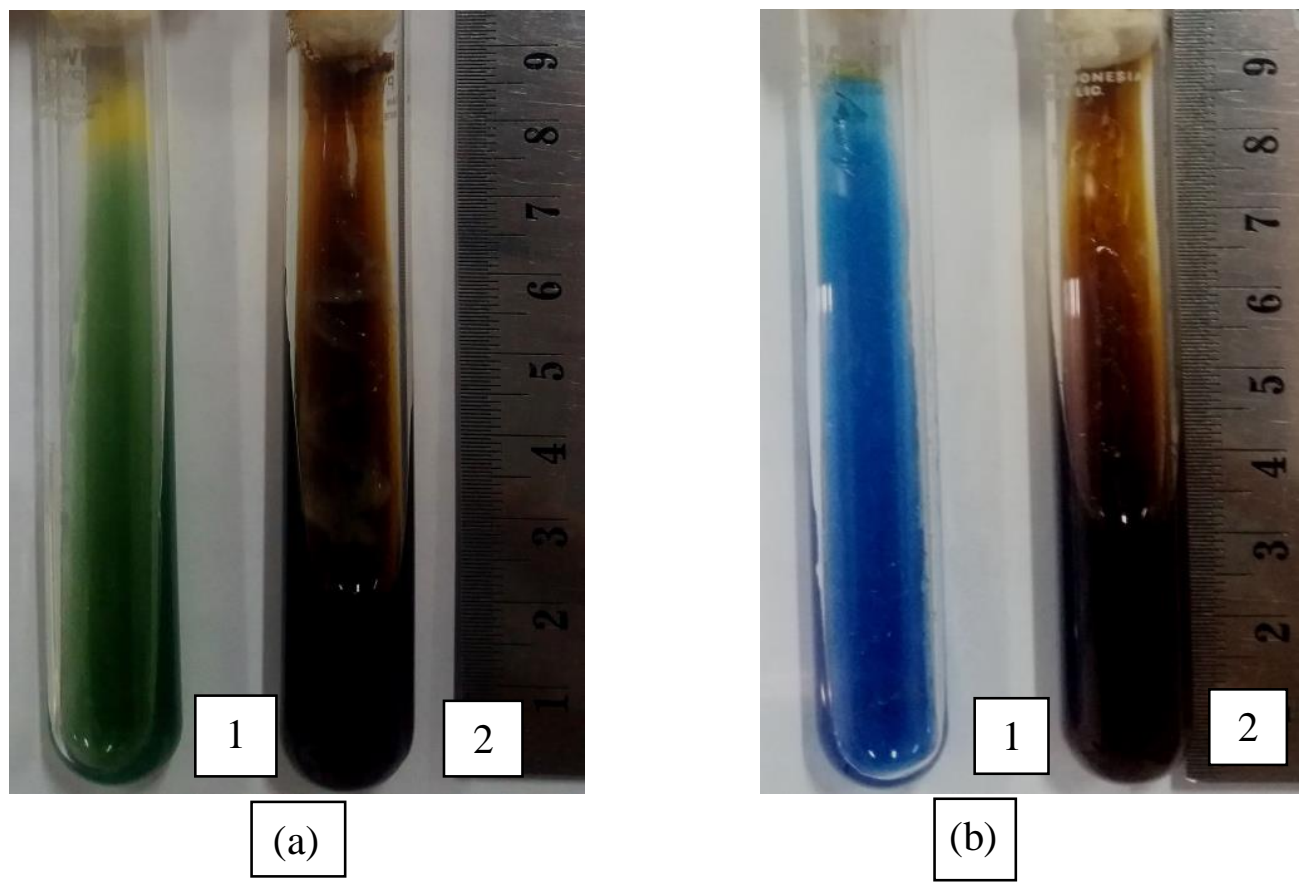

Gambar 6. Hasil uji (1) Citrate dan (2) KIA pada (a) E. coli dan (b) Klebsiella spp.

\section{PEMBAHASAN}

Infeksi saluran kemih terjadi akibat adanya invasi patogen pada sistem urinaria yang memicu timbulnya respon peradangan (inflamasi) dari urotelial (Sibi et al., 2011). Bakteri E. coli menjadi penyebab paling sering terjadinya ISK dibandingkan dengan bakteri Gram negatif lainnya ataupun bakteri Gram positif (Getachew, 2010). Hasil penelitian Kibret dan Abera (2014) menunjukkan bahwa E. coli dominan ditemukan pada sampel urine penderita ISK, selain bakteri tersebut, bakteri lain yang ditemukan adalah Klebsiella spp., Citrobacter spp., Staphylococcus aureus, Coagulase Negative Staphylococci (CoNS), dan ada pula jamur Candida spp. (Yadav et al., 2014).

Coagulase Negative Staphylococci (CoNS) merupakan kelompok bakteri
Staphylococcus yang memiliki hasil koagulase negatif dan resisten terhadap antibiotik, serta dominan ditemukan sebagai penyebab infeksi nosokomial. Staphylococcus haemolyticus, $S$. saprophyticus, $S$. hominis, $S$. capitis, dan $S$. equorum merupakan beberapa jenis CoNS yang ditemukan pada pasien ICU Rumah Sakit DR. Soetomo Surabaya (Trisnadewi et al., 2014). Infeksi hematogen pada ginjal kemungkinan terjadi jika dalam urine ditemukan adanya kelompok Staphylococcus (Becker et al., 2014).

Hasil pada penelitian ini menunjukkan $E$. coli ditemukan pada $40 \%$ sampel urine pasien ISK Rumah Sakit Bhayangkara Kediri (Gambar 1), selain itu, hasil isolasi juga menunjukkan adanya Klebsiella spp. pada sampel 8, 12, dan 16 (Tabel 1). Hal ini seperti yang dikemukakan pada hasil penelitian Samirah et 
al. (2014) dan Yadav et al. (2014) yaitu E. coli menjadi bakteri terbanyak yang ditemukan pada penderita ISK, kemudian diikuti Klebsiella spp. Hasil tersebut didapatkan dari pengamatan pada media MCA dan biokimia reaksi (Tabel 1 dan Tabel 2). Penelitian ISK pada pasien di RSUP Dr. Soetomo Surabaya menunjukkan hasil yang berbeda dengan penelitian ini. Pada penelitian tersebut, Klebsiella pneumoniae lebih banyak ditemukan dibanding E. coli (Muhajir et al., 2016). Bakteri Gram positif seperti Salmonella sp., Shigella sp., Proteus sp., dan Pseudomonas sp. tidak tumbuh pada MCA karena adanya kandungan garam empedu dan crystal violet (Jawetz et al., 2013).

Escherichia coli ataupun Klebsiella spp. memiliki kemampuan yang sama dalam memfermentasi laktosa. Mac Conkey Agar (MCA) merupakan media selektif bakteri Gram negatif. Salah satu komposisi MCA yaitu laktosa menjadi sumber karbohidrat bakteri batang Gram negatif sekaligus digunakan untuk mengetahui ke-mampuan bakteri dalam memfermentasi laktosa. Bakteri yang mampu memfermentasi laktosa antara lain E. coli, Klebsiella sp., Enterobacter aerogenes, dan Citrobacter sp. Spesies Citrobacter sp. juga dapat menimbul-kan ISK. Kemampuan fermentasi laktosa yang lambat menjadikan pertumbuhan Citrobacter sp. tidak dapat diamati apabila waktu inkubasi kurang dari 48 jam. Hal tersebut dikarenakan pada penelitian ini waktu inkubasi yang digunakan hanya 24 jam sehingga hanya koloni bakteri yang memiliki kemampuan fermentasi laktosa dalam waktu kurang dari 24 jam yang dapat diamati, seperti E. Coli dan Klebsiella pneumoniae (Jawetz et al., 2013). Pada media MCA, produksi asam ditandai dengan perubahan warna koloni bakteri yang semula merah (neutral red pada MCA) berubah menjadi merah muda (pink) akibat absorbansi neutral red karena adanya penurunan $\mathrm{pH}$ (asam) (Champoux et al., 2004). Kemampuan bakteri memfermentasi laktosa juga ditunjukkan dengan terbentuknya gas dan produksi asam pada media KIA dan media uji fermentasi gula (Jawetz et al., 2013).

Escherichia coli merupakan flora normal di saluran pencernaan (Jawetz et al., 2013). Bakteri tersebut tumbuh dengan cepat pada suasana aerob dan anaerob, dapat memfermentasi glukosa, dan bersifat oksidasi negatif (Champoux et al., 2004). Mikroorganisme seperti $E$. coli dapat masuk ke saluran kemih melalui beberapa cara yaitu ascending, hematogen, limfogen, ataupun penularan secara langsung dari organ-organ di sekitar yang telah mengalami infeksi. Sebanyak 90\% kasus ISK yang disebabkan $E$. coli tidak mengakibatkan adanya komplikasi, namun dapat menyebabkan kekambuhan selama 12 bulan setelah infeksi tersebut sembuh (Israr, 2009). Gejala ISK akibat infeksi E. coli terlihat dari frekuensi ingin berkemih yang tinggi namun hanya mengeluarkan sedikit urine, hematuria, disuria, dan piuria (Jawetz et al., 2013).

Sebanyak $50 \%$ sampel urine menunjukkan hasil negatif (tidak ditemukan bakteri) (Gambar 1). Hal tersebut kemungkinan besar karena pasien sudah diberikan pengobatan berupa antibiotik. Di Rumah Sakit Bhayangkara Kediri, jenis antibiotik yang diberikan pada pasien ISK saat penelitian ini berlangsung adalah amoxillin. Amoxillin merupakan antibiotik penicillin semi sintetik yang termasuk dalam kelompok antibiotik Beta-Lactamase (Elmolla \& Chaudhuri, 2010).

Penelitian Mahesh et al. (2011) menunjukkan bahwa $E$. coli ditemukan pada hasil isolasi urine penderita ISK. Pada penelitian tersebut, E. coli yang ditemukan ditunjukkan dengan hasil positif aktivitas Extended Spectrum Beta-Lactamase (ESBL). Extended Spectrum Beta-Lactamase (ESBL) adalah enzim hidrolitik yang dimiliki kelompok bakteri Gram negatif sepeti E. coli dan Klebsiella spp. untuk menghidrolisis cincin beta laktam (Muhajir at al., 2016). Apabila cincin tersebut lisis, maka akan terjadi peningkatan resistensi bakteri terhadap antibiotik, seperti penicillin ataupun kelompok antibiotik aztreonam (Katzung, 2002).

Kasus ISK, infeksi sering terjadi secara ascending yaitu bakteri masuk melalui uretra kemudian bakteri akan mengalami multiplikasi dan binding dalam vesika urinaria. Bakteri dari vesika urinaria selanjutnya masuk ke ginjal. Pertambahan usia dan aktivitas seksual menjadi salah satu penyebab peningkatan jumlah penderita ISK (Samirah et al., 2006). Kejadian ISK tidak hanya disebabkan oleh 
infeksi bakteri, tetapi juga karena terjadinya penurunan kompetitor adesi patogen di dalam tubuh akibat sistem imun host yang terganggu (Israr, 2009).

\section{SIMPULAN}

Escherichia coli ditemukan pada $40 \%$ sampel urine penderita ISK di RS Bhayangkara Kediri. Penelitian selanjutnya, sebaiknya dilakukan pengelompokkan sampel berdasarkan usia dan jenis kelamin pasien, sehingga diperoleh informasi tentang kecenderungan gender dan usia penderita ISK di RS Bhayangkara Kediri. Inokulasi sampel urine pada medium umum juga dapat dilakukan untuk mendapatkan lebih banyak kelompok bakteri dari sampel urine yang diteliti.

\section{REFERENSI}

Alkhyat, S. H., \& Al-Maqtari, M. A. (2014). Prevalence of microorganism isolates from urinary track infection at some hospitals in Sana'a City, Yemen. International Journal of Current Microbiology and Applied Sciences, 3(6), 876-885.

Becker, K., Hellmann, C., \& Peters, G. (2014). Coagulase-negative Staphylococci. Clinical Microbiology Reviews, 27(4), 870-926.

Bien, J., Sokolova, O., \& Bozko, P. (2012). Role of uropathogenic Escherichia coli virulence factors in development on urinary tract infection and kidney damage. International Journal of Nephrologi, 2012(2), 1-16.

Champoux, J. J., Neidhardt, F. C., Drew, W. L., \& Plorde, J. J. (2004). Enterobacteriaceae in Pathogenic Bacteria. In K. J. Ryan, \& C. G. Ray (Eds), Sherris medical microbiology fourth edition: an introduction to infectious diseases, (pp. 343-357). New York, USA: McDrawHill.

Darsono, P. V., Mahadiyah, D., \& Fahrianti, F. (2016). Gambaran karakteristik ibu hamil yang mengalami infeksi saluran kemih (ISK) di wilayah kerja Puskesmas Pekauman Banjarmasin. Dinamika Kesehatan, 7(1), 162-170.
Depkes RI. (2014). Survei demografi dan kesehatan Indonesia. Jakarta: Depkes RI.

Elmolla, E. S., \& Chaudhuri, M. (2010). Photocatalytic degradation of amoxicillin, ampicillin and cloxacillin antibiotics in aqueous solution using $\mathrm{UV} / \mathrm{TiO} 2$ and $\mathrm{UV} / \mathrm{H} 2 \mathrm{O} 2 / \mathrm{TiO} 2$ photocatalysis. Desalination, 252(1-3), 46-52.

Geografi, L., Wahyono, D., \& Yasin, N. M. (2014). Evaluasi penggunaan antibiotik untuk terapi infeksi saluran kemih pada pasien sindrom nefrotik pediatri. Jurnal Manajemen dan Pelayanan Farmasi, 4(1), 1-6.

Getachew, T. (2010). Bacterial pathogens implicated is causing urinary tract infection (UTI) and their antimicrobial susceptibility pattern in Ethiopia. Ciencias Biologicas, 41(1), 1-6.

Hemraj, V., Diksha, S., \& Avneet, G. (2013). A review on commonly used biochemical test for bacteria. Innovare Journal of Life Science, 1(1), 1-7.

Israr, Y. A. (2009). Infeksi saluran kemih. Riau: Universitas Riau.

Jarvis, T. R., Chan, L., \& Gottlieb, T. (2014). Assessment and management of lower urinary tract infection in adults. Australian Prescriber Journal, 37(1), 7-9.

Jawetz., Melnick., \& Adelberg's. (2013). Normal flora of the intestinal tract in normal microbial flora of the human body. In G. F. Brooks, K. C. Carroll, J. S. Butel, \& S. A. Morse (Eds), Medical Microbiology Twenty-Fourth Edition (pp. 199). New York, USA: McDrawHill.

Katzung, B. G. (2002). Farmakologi dasar dan klinik. Jakarta: EGC.

Kibret, M., \& Abera, B. (2014). Prevalence and antibiogram of bacterial isolates from urinary tract infections at Dessie Health Research Laboratory, Ethiopia. Asian Pacific Journal of Tropical Biomedicine, 4(2), 164-168.

Mahesh, E., Medha, Y., Indumathi, V. A., Kumar, P. S., Khan, M. W., \& Punith, K. (2011). Community-acquired urinary tract infection in the elderly. British Journal of Medical Practitioners, 4(1), 1-6. 
Mamonto, N. D., Soeliongan, S., \& Homenta, H. (2015). Identifikasi bakteri aerob pada urin porsi tengah pasien penyakit ginjal kronik stadium 5 di BLU RSUP Prof. R.D. Kandau Manado. Jurnal eBiomedik, 3(1), 211-215.

Muhajir, A. S., Purwono, P. B., \& Handayani, S. (2016). Gambaran terapi dan luaran infeksi saluran kemih oleh bakteri penghasil Extended Spectrum Beta Lactamase pada anak di RSUD Dr. Soetomo Surabaya. Sari Pediatri, 18(2), 111-116.

Nordstrom, L., Liu, C. M., \& Price, L. B. (2013). Foodborne urinary tract infections: a new paradigm for antimicrobial-resistant foodborne illness. Frontiers in Microbiology, 4(29), 1-6.

Prabowo, F. I., \& Habib, I. (2012). Identifikasi pola kepekaan dan jenis bakteri pada pasien infeksi saluran kemih di Rumah Sakit PKU Muhammadiyah Yogyakarta. Mutiara Medika, 12(2), 93-101.

Prakasam, K. C. A., Kumar, K. G. D., \& Vijayan, M. (2012). A cross sectional study on distribution of urinary tract infection and their antibiotic utilisation pattern in Kerala. International Journal of Research in Pharmaceutical and Biomedical Science, 3(3), 1125-1130.

Samirah., Darwati., Windarwati., \& Hardjoeno. (2006). Pola dan sensitifitas kuman di penderita infeksi saluran kemih. Indonesian Journal of Clinical Pathology and Medical Laboratory, 12(3), 110-113.
Sibi, G., Devi, A. P., Fouzia, K., \& Patil, B. R. (2011). Prevalence microbiologic profile of urinary tract infection and its treatment with Trimethoprim in diabetic patients. Research Journal of Microbiology, 6(6), 543-551.

Sumolang, S. A. C., Porotu'o, J., \& Soeliongan, S. (2013). Pola bakteri pada penderita infeksi saluran kemih di BLU RSUP Prof.dr.R.D. Kandau Manado. Journal e-Biomedik, 1(1), 597-601.

Swetha, V. V., Rao, U. S., Prakash, P. M., \& Subbarayudu, S. (2014). Aerobic bacteriological profile of urinary tract infections in a tertiary care hospital. International Journal of Current Microbiology and Applied Sciences, 3(3), 120-125.

Trisnadewi, I. G. A., Suharjono., Hardiono., \& Widodo, A. D. W. (2014). Analysis of antibiotic usage in patients with bacteremia in the ICU Unit of DR. Soetomo Hospital Surabaya. Folia Medica Indonesia, 50(4), 254-261.

Yadav, S., Siwach, S., Goel, S., \& Rani, P. (2014). Prevalence of asympatomatic urinary tract infection in pregnancy in rural area. International Journal of Current Microbiology and Applied Sciences, 3(3), 159-163. 